\title{
Туристский бренд территории как составляющая формирования туристского образа Кемеровской области (Кузбасса)
}

\author{
Ф.Ю. Кайзер $\bowtie$ \\ Кемеровский государственный университет, Российская Федерация \\ (650000, ул. Красная, 6, г. Кемерово) \\ Поступила в редакиию 13.06.2019 \\ Принята к публикаиии 26.02.2020
}

\begin{abstract}
Аннотация: Цель исследования заключается в выявлении существующих и перспективных брендов Кузбасса, на основании которых возможно позиционирование Кемеровской области на российском и зарубежном туристском рынке. Материальь и методы. Для достижения цели автором применен социологический метод исследования (анкетирование), с помощью которого удалось выявить потенциальные туристские бренды, основные ассоциации, а также привлекательные и непривлекательные стороны для отдыха и туризма в Кемеровской области по мнению респондентов из разных регионов России. Исследование проводилось в два этапа посредством интернет-опроса в социальных сетях (ВКонтакте, Facebook, Одноклассники), опроса на платформе Google Forms, электронной почты, а также личного анкетирования. Методика проведения опроса предполагала, что респонденты, отвечая на предложенные вопросы, могут называть одновременно несколько вариантов ответов (следствием этого является отклонение от $100 \%$ ). Результаты исследования показали, что в Кемеровской области существуют неофициальные бренды-лидеры, которые в будущем могут стать официальным туристским символом региона. Помимо этого, выявленные привлекательные и непривлекательные факторы для отдыха показали неоднозначную ситуацию развития туризма в Кузбассе. Таким образом, создание, развитие и продвижение туристского бренда Кемеровской области играет важную роль в туристско-рекреационном направлении. Это способствует укреплению туристского образа региона на туристском рынке.
\end{abstract}

Ключевые слова: туристский бренд территории, опрос, респондент, Кемеровская область, туристский образ.

\section{Tourist Brand Territory as a Component of the Formation of Tourist Image Kemerovo Region (Kuzbass)}

\begin{abstract}
Ph. J. Kaizer $\bowtie$
Abstract: The problem discussed in the article is the results of a study of Kemerovo region tourist brand as important component in the formation of a region tourist image. The study purposes to identify existing and promising brands of Kuzbass, on the basis of which it is possible to position the Kemerovo region on the tourism market. The author has been applied a sociological method by which was possible to identify potential tourist brands, major associations, attractive and unattractive tourism factors in the region. The study carried out in two stages through an online survey on social networks, Google Forms platform, e-mail and personal questionnaire. The survey methodology assumed that respondents answering the proposed questions can name several answers at the same time. The results of research showed that in the Kemerovo region there are unofficial leading brands that can become the official region tourist symbol in the future. In addition, the identified attractive and unattractive factors for recreation showed an ambiguous situation in the development of tourism in Kuzbass. In conclusion, the creation, development and promotion of the tourist brand of the Kemerovo region plays an important role in the tourist and recreational direction.
\end{abstract}

(C) Кайзер Ф.Ю., 2020

E-mail: filipp.kaizer@yandex.ru

(c) (i) Контент доступен под лицензией Creative Commons Attribution 4.0 License.

The content is available under Creative Commons Attribution 4.0 License.

Вестник ВГУ, Серия: География. Геоэкология, 2020, № 1, с. 67-76 
Key words: tourist brand of the territory, survey, respondent, Kemerovo region, tourist image (destination image).

\section{ВВЕДЕНИЕ}

Когда речь идет об имидже страны, региона, города, прежде всего, имеют в виду запоминающийся образ, отличительные особенности данной территории от других. Важной составляющей туристского образа территории является ее бренд. Бренд является частью общего потенциала города, региона, страны и создает дополнительную ценность и привлекательность в глазах потребителей. В связи с этим, создание, развитие и продвижение туристского бренда территории играет важную роль в туристско-рекреационном направлении. Это способствует созданию, развитию и укреплению образа региона на туристском рынке.

Общенаучной базой изучения туристского бренда послужили труды отечественных и зарубежных экономистов, социологов, географов $[1,2$, $6,7,11,13,14]$.

Бренд территории часто определяют как известный объект или совокупность объектов природного, культурно-исторического наследия, а также маршрут, который охватывает посещение данных объектов, занятия, услуги, ремесла, уникальные события. В частности, О. Е. Афанасьев указывает следующее значение термина: «Бренд - это те достопримечательности региона, которые показывают гостям в первую очередь, без ознакомления с которыми знакомство с данной местностью считается неполным. Именно с помощью формирования и продвижения бренда регион становится более привлекательным» [1].

Д. В. Визгалов определяет бренд региона как «особая территориальная идентичность, проявляющаяся в специальных, креативных идеях, исторических и культурных детерминантах, формирующих особый статус региона» $[6,10]$. Г. Ханов считает, что «бренд территорий - это комплекс инструментов PR и CMИ, направленных на формирование положительного восприятия имиджа объекта. То есть имидж - это специфический образ в сознании индивида, а репутация - объем преимуществ, выгодно отличающий один регион от другого» ${ }^{1}[10]$.

Достаточно интересный, на наш взгляд, подход к определению бренда приводит В. С. Блашенкова, рассматривая бренд с двух позиций. Бренд

${ }^{1}$ Ханов Г. Киров как бренд неузнаваем // Navigatorkirov.ru: [бизнес-портал]. URL: http://www.navigatorkirov.ru/ interview/260.html (дата обращения 09.01.2015). территории - это, с одной стороны, набор устойчивых обещаний, которые дает регион своим целевым группам, а с другой - сложившаяся сумма всех впечатлений, получаемых этими целевыми группами. Если, при условии грамотного брендинга территории, устойчивые обещания совпадают со сложившейся суммой впечатлений у целевой аудитории, то у этой территории формируется цельный образ региона [2].

В основе формирования туристских брендов лежит осознанная работа с ее внутренними ресурсами. При создании концепции позиционирования как опорные точки могут восприниматься разнообразные объекты: исторические события, памятники культуры, природные ресурсы, промышленные объекты, известные мероприятия, проводимые в регионе, а также известные личности, посещавшие или проживающие на этой территории. В процессе изучения специальной литературы по теме исследования, нами было взято за основу следующее определение туристского бренда территории - это уникальный эмоционально-позитивный образ, обусловленный социально-экономическими, природными, историческими, культурными и другими особенностями территории, ставший широко известным общественности через положительные ассоциации, в дальнейшем побуждающие к посещению территории и напоминающие о ней.

\section{МАТЕРИАЛЫ И МЕТОДЫ ИССЛЕДОВАНИЯ}

Поскольку бренд территории является неотъемлемой частью для успешного формирования ее туристского образа, нами было проведено исследование, направленное на выявление брендов Кемеровской области, а также основных ассоциаций, привлекательных и непривлекательных сторон для отдыха и туризма в Кемеровской области. Исследование проводилось с 2012 по 2016 год посредством интернет-опроса в социальных сетях (ВКонтакте, Facebook, Одноклассники), опроса на платформе GoogleForms, электронной почты, а также личного анкетирования. Методика проведения опроса предполагала, что респонденты, отвечая на предложенные вопросы, могут называть одновременно несколько вариантов ответов (следствием этого является отклонение от $100 \%$ ).

В рамках исследования был проведен опрос жителей Кемеровской области, граничащих с ней субъектов РФ (Новосибирская область, Томская область, Красноярский край, Республика Хакасия, 
Количество респондентов по регионам (чел.)

[Table 1. Number of respondents by regions (people)]

\begin{tabular}{|c|c|c|c|c|c|}
\hline $\begin{array}{c}\text { Всего } \\
\text { [Total] }\end{array}$ & $\begin{array}{c}\text { Кемеровская } \\
\text { область } \\
\text { [Kemerovo } \\
\text { region] }\end{array}$ & $\begin{array}{c}\text { Соседние } \\
\text { Регионы } \\
\text { [Neighboring } \\
\text { Regions] }\end{array}$ & $\begin{array}{c}\text { Урал } \\
\text { [Ural] }\end{array}$ & $\begin{array}{c}\text { Европейская } \\
\text { часть РФ } \\
\text { [European part of } \\
\text { the RF] }\end{array}$ & $\begin{array}{c}\text { Забайкалье и } \\
\text { Дальний Восток } \\
\text { [Transbaikalia and } \\
\text { Far East] }\end{array}$ \\
\hline 914 & 280 & 150 & 132 & 212 & 140 \\
\hline
\end{tabular}

Таблииа 2

Основные ассоциации, связанные с Кемеровской областью у жителей разных регионов РФ (\%)

[Table 2. Main associations with the Kemerovo region among residents of different regions of the Russian Federation (\%)]

\begin{tabular}{|c|c|c|c|c|c|c|c|c|c|}
\hline $\begin{array}{c}\text { Мнения } \\
\text { респондентов } \\
\text { [Respondents } \\
\text { opinions] }\end{array}$ & $\begin{array}{l}\text { 量 } \\
\text { 元 }\end{array}$ & 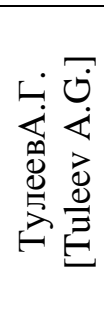 & 胥 & $\begin{array}{ll} & \\
0 & 3 \\
0 & 0 \\
0 & 0 \\
0 & 0 \\
0 & 0 \\
0 & 0\end{array}$ & 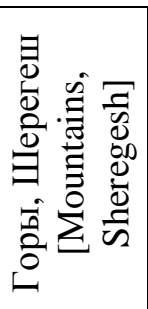 & 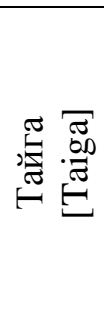 & 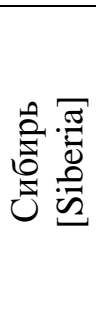 & 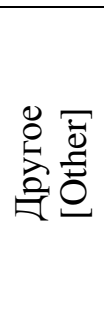 & 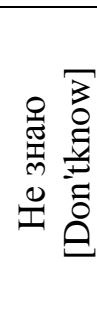 \\
\hline $\begin{array}{l}\text { Кемеровская } \\
\text { область } \\
\text { [Kemerovo } \\
\text { region] }\end{array}$ & 75 & 16 & 7,1 & 7,1 & 5,7 & 5,7 & 0 & 15,7 & 0 \\
\hline $\begin{array}{l}\text { Соседние } \\
\text { регионы } \\
\text { [Neighboring } \\
\text { Regions] }\end{array}$ & 80 & 60 & 0 & 0 & 33,3 & 13,3 & 0 & 20 & 2,2 \\
\hline $\begin{array}{l}\text { Урал } \\
\text { [Ural] }\end{array}$ & 45,5 & 0 & 0 & 9,1 & 0 & 4,1 & 27,3 & 18,2 & 9,1 \\
\hline $\begin{array}{l}\text { Европейская } \\
\text { часть России } \\
\text { [European part } \\
\text { of the RF] }\end{array}$ & 26,4 & 1,9 & 0 & 5,6 & 0 & 5,6 & 3,7 & 20,7 & 71,7 \\
\hline $\begin{array}{l}\text { Забайкалье и Д. } \\
\text { Восток } \\
\text { [Transbaikaliaan } \\
\text { dFarEast] }\end{array}$ & 25,8 & 5 & 0 & 10,2 & 5,2 & 10 & 10,3 & 5,2 & 5 \\
\hline
\end{tabular}

Республика Алтай, Алтайский край), некоторых регионов Урала (Свердловская область, Пермский край, Республика Башкортостан), регионов Европейской части РФ (Москва, Санкт-Петербург, Ярославль, Казань), а также жителей Забайкалья и Дальнего Востока (Чита, Хабаровск, Петропавловск-Камчатский).

На первом этапе (2012-2013) в опросе участвовали респонденты из Кемеровской области, регионов-соседей, Урала, Забайкалья и Дальнего Востока, ряда регионов европейской части России. Всего было опрошено 914 человек, распределение респондентов по регионам приведено в таблице 1.
Прежде чем выявлять туристские бренды нашего региона, мы поставили задачу выяснить у респондентов, насколько хорошо они осведомлены о Кемеровской области и с чем у них ассоциируется регион. Анализ ответов жителей разных регионов России показал, что представления о Кемеровской области существенно отличаются в зависимости от удаленности этих регионов от Кузбасса.

Респонденты отдаленных от Кемеровской области регионов на вопрос о расположении Кузбас$c a$, в основном отвечали, что регион расположен в Сибири, на севере, за Уралом. Самые «экзотические» представления имеют некоторые жители За- 
Привлекательные и непривлекательные факторы для отдыха и туризма в Кемеровской области по мнению жителей разных регионов

[Table 3. Attractive and unattractive factors for recreation and tourism in the Kemerovo region according to residents of different regions]

\begin{tabular}{|c|c|c|}
\hline $\begin{array}{c}\text { Мнения } \\
\text { респондентов } \\
\text { [Respondents } \\
\text { opinions] }\end{array}$ & $\begin{array}{l}\text { Привлекательные факторы } \\
\text { [Attractive factors] }\end{array}$ & $\begin{array}{l}\text { Непривлекательные факторы } \\
\text { [Unattractive factors] }\end{array}$ \\
\hline $\begin{array}{l}\text { Кемеровской } \\
\text { области } \\
\text { [Kemerovo region] }\end{array}$ & $\begin{array}{l}\text { Развитие горнолыжного туризма, } \\
\text { музей-заповедник «Томская } \\
\text { Писаница», горнолыжный курорт } \\
\text { Шерегеш, много интересных } \\
\text { исторических мест, город-музей под } \\
\text { открытым небом Мариинск, богатая } \\
\text { природа, разнообразие животного и } \\
\text { растительного мира }\end{array}$ & $\begin{array}{l}\text { Недостаточно развитая } \\
\text { инфраструктура, холодная и } \\
\text { продолжительная зима, суровый } \\
\text { климат, удаленность от Европейской } \\
\text { части России, много шахт и } \\
\text { промышленных предприятий, } \\
\text { дорогие цены на отдых, плохая } \\
\text { экология, труднодоступность для } \\
\text { иностранцев }\end{array}$ \\
\hline $\begin{array}{l}\text { Соседних регионов } \\
\text { [Neighboring } \\
\text { Regions] }\end{array}$ & $\begin{array}{l}\text { Горнолыжный курорт Шерегеш, } \\
\text { географически близкий регион, } \\
\text { хорошее качество дорог, хороший } \\
\text { губернатор, много шахт для } \\
\text { индустриального туризма, много } \\
\text { историко-культурных и природных } \\
\text { памятников }\end{array}$ & $\begin{array}{l}\text { Плохая экология, холодно, далеко от } \\
\text { морей, далеко от столичного } \\
\text { региона, резко континентальный } \\
\text { климат, много шахт, недостаточно } \\
\text { туристской информации о регионе }\end{array}$ \\
\hline $\begin{array}{l}\text { Урала } \\
\text { [Ural] }\end{array}$ & $\begin{array}{l}\text { Разнообразный климат, горный } \\
\text { рельеф, национальные парки, тайга }\end{array}$ & $\begin{array}{l}\text { Плохая экология, недостаточно } \\
\text { развитая инфраструктура, далеко от } \\
\text { Урала, холодно, мало } \\
\text { достопримечательностей }\end{array}$ \\
\hline $\begin{array}{l}\text { Европейской часть } \\
\text { России } \\
\text { [European part of } \\
\text { the RF] }\end{array}$ & $\begin{array}{l}\text { Красивая природа, горнолыжные } \\
\text { курорты, нет пробок, экстремальные } \\
\text { условия для туризма, «Сибирская } \\
\text { Швейцария» - Шерегеш }\end{array}$ & $\begin{array}{l}\text { Местоположение, нет моря, } \\
\text { удаленность от Москвы. Мало } \\
\text { информации о регионе, много шахт, } \\
\text { плохая экология, далеко и дорого } \\
\text { лететь, суровый климат }\end{array}$ \\
\hline $\begin{array}{l}\text { Забайкалья и } \\
\text { Д. Востока } \\
\text { [Transbaikalia and } \\
\text { Far East] }\end{array}$ & $\begin{array}{l}\text { Тайга, горнодобывающие } \\
\text { предприятия для индустриального } \\
\text { туризма, чистый горный воздух, } \\
\text { богатый регион, ближе к Москве, } \\
\text { чем Дальний Восток, красивая } \\
\text { природа }\end{array}$ & $\begin{array}{l}\text { Далеко от Москвы, и от Дальнего } \\
\text { Востока, нет моря, нет летних } \\
\text { курортов, холодно, плохая экология }\end{array}$ \\
\hline
\end{tabular}

байкалья и Дальнего Востока, которые считают, что Кемеровская область расположена рядом с Москвой, на Урале, на юге России.

Ответы на вопрос: $C$ чем у Вас ассоииируется Кемеровская область, показали, что у большинства кузбассовцев и у наших соседей (75\% и $80 \%$ опрошенных соответственно) регион ассоциируется с углем, угледобывающей промышленностью. Фактически, можно утверждать, что уголь является промышленным брендом региона. Второе место по популярности занимает «бренд личности» губернатор области (с 2018 года экс-губернатор) А. Г. Тулеев (16\% и $60 \%$ соответственно).

Необходимо отметить, что у жителей соседних регионов достаточно популярной ассоциацией с нашей областью является горнолыжный курорт «Шерегеш». У респондентов из отдаленных регионов Кузбасс также чаще всего ассоциируется с углем. Среди других ответов можно выделить Сибирь, холод, тайгу, медведей и другие варианты. У жителей нашего региона среди других ассоциаций были названы СДС (АО ХК «Сибирский деловой 
союз»), Мариинский ликеро-водочный завод и другие. Подробный анализ приведен в таблице 2.

Из основных достопримечательностей, которыми известна Кемеровская область, кузбассовцы называют заповедник «Кузнецкий Алатау», туристско-рекреационный центр «Танай», Кузнецкая крепость, музей-заповедник «Красная горка», памятники природы «Липовый остров» и «Спасские дворцы». У наших соседей наиболее известными объектами являются Танай, Кузнецкая крепость, заповедник «Кузнецкий Алатау», Поднебесные зубья, Мариинский ликеро-водочный завод. Респонденты отдаленных территорий знают в основном о заповеднике «Кузнецкий Алатау», Шорском национальном парке, музее-заповеднике «Красная горка». Исследования показали, что самыми популярными местами у респондентов, участвующих в опросе регионов, являются горнолыжный курорт «Шерегеш» и музей-заповедник «Томская Писаница».

Важнейшей объективной составляющей туристского бренда Кемеровской области является анализ привлекательных и непривлекательных (позитивных и негативных) факторов для отдыха и туризма, который позволит отобразить совокупность ее конкурентных преимуществ и недостатков. Они обусловливаются экономическими, социальными, природными, культурными особенностями региона, территориальной удаленностью и транспортной доступностью, инфраструктурой, состоянием производственного потенциала и сложившимся уровнем инвестиционной активности. Очевидно, что конкурентные преимущества способствуют усилению конкурентоспособности территории на туристском рынке, а конкурентные недостатки осложняют процесс ее включения в туристское пространство. Мнения респондентов представлены в таблице 3.

Основные попытки формирования туристского образа Кемеровской области включают, в том числе, формирование и продвижение брендов нашего региона. Так, за последние несколько лет Кузбасс позиционирует себя как место обитания «снежного человека». В период с 2012 по 2014 годы велась активная и весьма масштабная PR-кампания по продвижению данного бренда, направленная на то, чтобы «снежный человек» стал своеобразной визитной карточкой региона. В этот период, при поддержке администрации области, был разработан целый ряд мероприятий по созданию и продвижению нового бренда Кузбасса - «Йети» [4].

Примерами таких мероприятий могут служить продвижение в СМИ туристского маршрута «По следам снежного человека», который включал в себя посещение Азасской пещеры, реализация сувенирной продукции с изображением Йети, а в Таштаголе и поселке Шерегеш «снежному человеку» был установлен целый ряд памятников и скульптур. По всей Кемеровской области проводились развлекательные мероприятия, включающие в себя флешмобы, конкурсы рисунков и т. д., а в СК «Арена» открылось и ныне действует кафе «Кузбасский Йети». В начале ноября в регионе ежегодно отмечается День рождения Йети, который приурочен к официальному открытию горнолыжного сезона в Шерегеше.

В рамках первого этапа исследования также был проведен опрос, направленный на выявление туристского бренда (символа, визитной карточки) Кемеровской области. На основе ответов респондентов о достопримечательностях и популярных (известных) местах Кемеровской области нами был составлен Топ-10 туристских символов Кузбасса. Респондентам из Кемеровской области было предложено выбрать 5 из 10 брендов, которые, по их мнению, служат или могут служить в качестве туристского символа региона. Результаты проведенного опроса представлены в таблице 4 и на рисунке 1.

Большинство жителей Кемеровской области (73,6\%) отдали свои предпочтения горнолыжному курорту «Шерегеш». Это обусловлено тем, что данный туристский объект занимает лидирующие позиции по популярности и посещаемости не только среди отдыхающих из Кузбасса, но и туристов со всей России. Лишь на $3 \%$ Шерегешу уступает музей-заповедник «Томская Писаница», который по праву считается лидером по историко-культурному, событийному и развлекательному туризму в регионе.

«Томская Писаница» является одним из главных туристских объектов, который посещают не только кузбассовцы, но и многие туристы из других субъектов России. Анализ ответов респондентов также показал, что Йети как туристский бренд территории, благодаря активному продвижению региональными властями и бизнесом, является популярным у жителей Кемеровской области и занимает 3 место в рейтинге, основанного на опросе жителей региона за 2012-2013 годы.

Участники маркетинга данного бренда пытались привлечь туристов и общественность, создать туристский имидж Кемеровской области за счет «Снежного человека» по аналогии с некоторыми регионами России, где им это удалось. Так, в каче- 
Рейтинг туристских брендов среди жителей Кемеровской области за 2012-2013

[Table 4. Rating of tourist brands among residents in the Kemerovo region, \% (2012-2013)]

\begin{tabular}{|l|c|c|}
\hline \multirow{2}{*}{$\begin{array}{c}\text { Туристский бренд (символ) } \\
\text { [Tourist brand (symbol)] }\end{array}$} & \multicolumn{2}{|c|}{$\begin{array}{c}\text { 2012-2013 гг. } \\
(280 \text { чел./100\%) }\end{array}$} \\
\cline { 2 - 3 } & Чел. & $\%$ \\
\hline ГК «Шерегеш» & 206 & 73,6 \\
\hline «Томская Писаница» & 193 & 58,6 \\
\hline Снежный человек (Йети) & 164 & 52,8 \\
\hline «Кузнецкая крепость» & 148 & 43,6 \\
\hline «Кузбасс» & 122 & 41,8 \\
\hline «Красная горка» & 117 & 40 \\
\hline ГК «Танай» & 112 & 37,1 \\
\hline Город-музей Мариинск & 104 & 10 \\
\hline Другое & 28 & 0 \\
\hline Шестаковский комплекс & 0 & \\
\hline
\end{tabular}

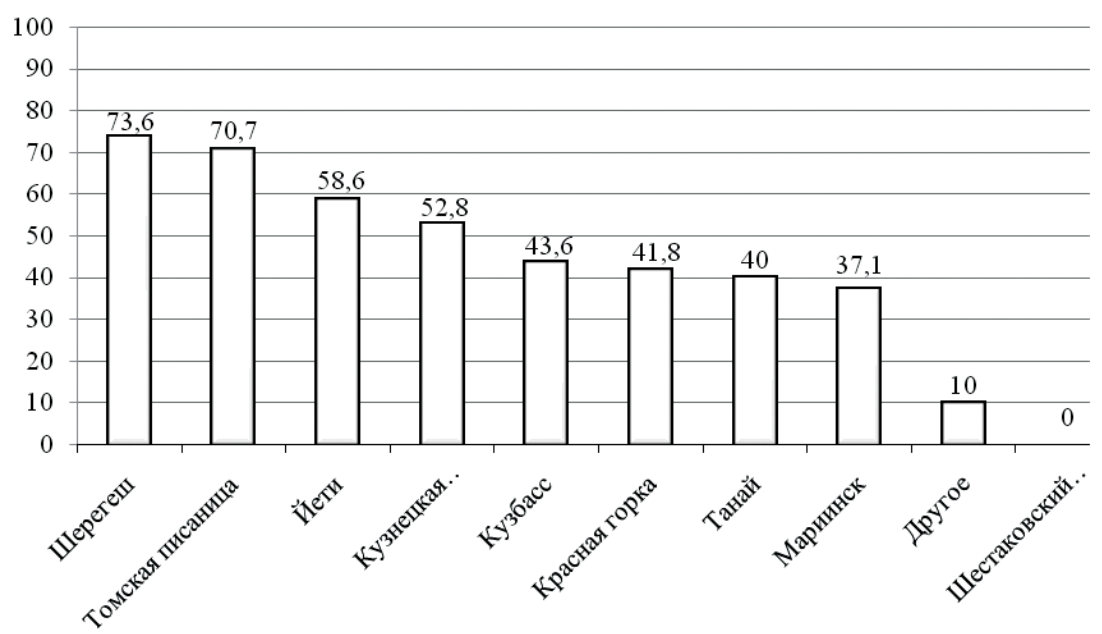

Puc. 1. Рейтинг туристских брендов среди жителей Кемеровской области в \% (2012-2013 гг.)

[Fig. 1. Rating of tourist brands among residents in the Kemerovo region, \% (2012-2013)]

стве российского опыта в вопросе брендинга можно выделить достаточно успешно развивающийся и набирающий популярность бренд «Великий Устюг - Родина Деда Мороза». Каждый год Вологодскую область посещают около 200 тысяч туристов не только российских, но и зарубежных. Целенаправленная политика продвижения туристского бренда Вологодской области реализуется в рамках концепции устойчивого развития. По аналогии с «Дедом Морозом» - брендом Вологодской области, «Йети» должен стать отличительным символом, брендом Кузбасса, который позволил бы идентифицировать регион на туристском рынке страны [4].

На втором этапе исследования (2015-2016 гг.) нами был проведен повторный опрос жителей Кемеровской области, целью которого было выявить, изменилось ли мнение кузбассовцев о туристском бренде региона. Результаты опроса за 20152016 годы представлены на рисунке 2.

Опрос, проведенный в два этапа с разницей в три года, позволил нам сопоставить и сравнить его результаты, которые представлены в таблице 5 и на рисунке 3.

\section{РЕЗУЛЬТАТЫ И ИХ ОБСУЖДЕНИЕ}

По результатам опроса 2015-2016 годов видно, что ситуация за три года для первых двух позиций не изменилась. Горнолыжный курорт «Шерегеш» по-прежнему занимает ведущую позицию $(81,2 \%)$, немного уступает музей-заповедник «Томская Писаница» $(75,8 \%)$, оставаясь на втором месте. Но важно отметить, что по сравнению с предыдущими годами, оба символа набрали больше 


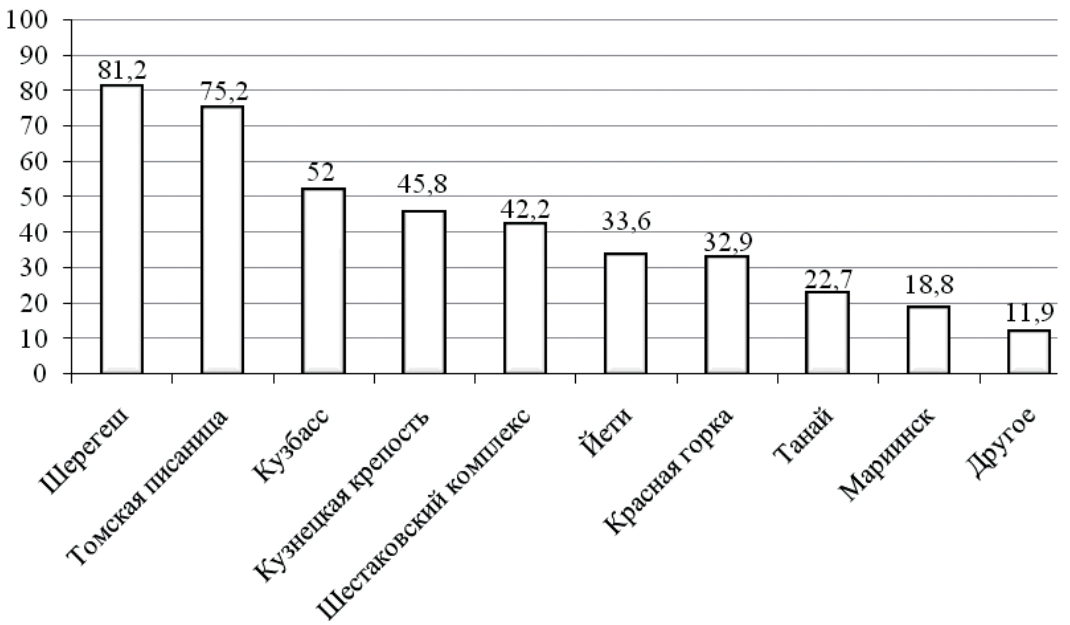

Puc. 2. Рейтинг туристских брендов среди жителей Кемеровской области в \% (2015-2016 гг.)

[Fig. 2. Rating of tourist brands among residents in the Kemerovo region, \% (2015-2016)]

голосов, что говорит о росте их популярности у жителей региона и туристов.

Третье место в рейтинге 2015-2016 годов занимает бренд «Кузбасс» $(52 \%)$, который в 20122013 годов занимал пятое место. Результаты данного опроса также показали, что само слово «Кузбасс» можно по праву считать не только визиткой угольного региона, но и его туристским брендом. Респонденты при этом отмечают, что промышленный бренд может одновременно являться и туристским. Устоявшийся многолетний бренд Кузбасса - уголь, и имидж промышленного региона, можно выгодно повернуть в сторону развития промышленного (индустриального) туризма. Интересным объектом для туристов, особенно иностранных, может стать неповторимый колорит шахтерских городов Кузбасса. При правильном вложении дополнительных средств в развитие угольных городов Кузбасса, можно сформировать имидж края угля и культуры, ведь Кемеровская область характеризуется большим числом учреждений искусства, культуры и образования (более 1800) [3].

Рост популярности туристского бренда «Кузбасс» связан, в том числе, с созданием и развитием в регионе туристско-рекреационного кластера Кузбасса, развитие которого предусмотрено до 2025 года. Стратегической целью кластера является повышение конкурентоспособности предприятий туристско-рекреационного комплекса, продвижение внутреннего туристского продукта и расширение спектра туристских услуг в регионе [12].

На четвертой строчке рейтинга, как и на первом этапе исследования, закрепилась Кузнецкая крепость (45,8\%) - визитная карточка южной столицы Кузбасса, г. Новокузнецка, жители которого отдавали свои предпочтения именно этому бренду, так как достопримечательность является символом не только самого города, но и олицетворяет историко-культурное наследие Кузнецкой земли.

Пятую позицию занимает Шестаковский археологический комплекс $(42,2 \%)$, которого не было среди брендов на первом этапе исследования, так как его основное позиционирование началось в 2015 году. Следует отметить, что данная дестинация в настоящее время активно позиционирует себя как центр историко-культурного туризма в регионе, и анализ статистических данных по посещаемости этого объекта показывает увеличение туристского потока и возрастание интереса со стороны туристов. Напомним, что Шестаковский археологический комплекс является уникальным в своем роде, так как именно в этом месте ученые нашли отлично сохранившиеся останки древнего животного - Пситтокозавра Сибирского, что вызвало огромный интерес не только со стороны научного сообщества, но и туристов, которые с удовольствием посещают данный объект [5]. Тем более, что с 2015 года Кемеровский областной краеведческий музей и ряд туристских агентств организуют экскурсионные туры, популяризирующие данную территорию.

С третьей на шестую позицию переместился Йети, это связано с тем, что первый этап нашего исследования совпал с периодом активного продвижения данного бренда, как символа региона в целом. Велась масштабная PR-кампания по продвижению «Снежного человека» как туристского бренда Кемеровской области. Но, как показали исследования, данный бренд и на первом этапе и в настоящий период исследований особенно боль- 
Сравнительный анализ ответов жителей Кемеровской области о туристском бренде региона [Table 5. Comparative analysis of responses from residents in the Kemerovo region about the region's tourism brand]

\begin{tabular}{|l|c|c|c|c|}
\hline \multirow{2}{*}{\begin{tabular}{c}
\multirow{2}{*}{$\begin{array}{c}\text { Бренд (символ) } \\
{[\text { Вrand (symbol) })}\end{array}$} \\
\cline { 2 - 5 }
\end{tabular}} & \multicolumn{2}{|c|}{$\begin{array}{c}\text { 2012-2013 гг. } \\
(280 \text { чел./100\%) }\end{array}$} & \multicolumn{2}{c|}{$\begin{array}{c}2015-2016 \text { гг. } \\
(280 \text { чел./100\%) }\end{array}$} \\
\cline { 2 - 5 } ГК «Шерегеш» & 206 & 73,6 & 225 & 81,2 \\
\hline «Томская Писаница» & 193 & 70,7 & 210 & 75,8 \\
\hline $\begin{array}{l}\text { «Кузнецкая } \\
\text { крепость» }\end{array}$ & 148 & 52,8 & 127 & 45,8 \\
\hline «Кузбасс» & 122 & 43,6 & 144 & 52 \\
\hline «Красная горка» & 117 & 41,8 & 91 & 32,9 \\
\hline Мариинск & 104 & 37,1 & 52 & 18,8 \\
\hline Иети & 164 & 58,6 & 93 & 33,6 \\
\hline ГК «Танай» & 112 & 40 & 63 & 22,7 \\
\hline $\begin{array}{l}\text { Шестаковское } \\
\text { кладбище динозавров }\end{array}$ & 0 & 0 & 117 & 42,2 \\
\hline Другое & 28 & 10 & 33 & 11,9 \\
\hline
\end{tabular}

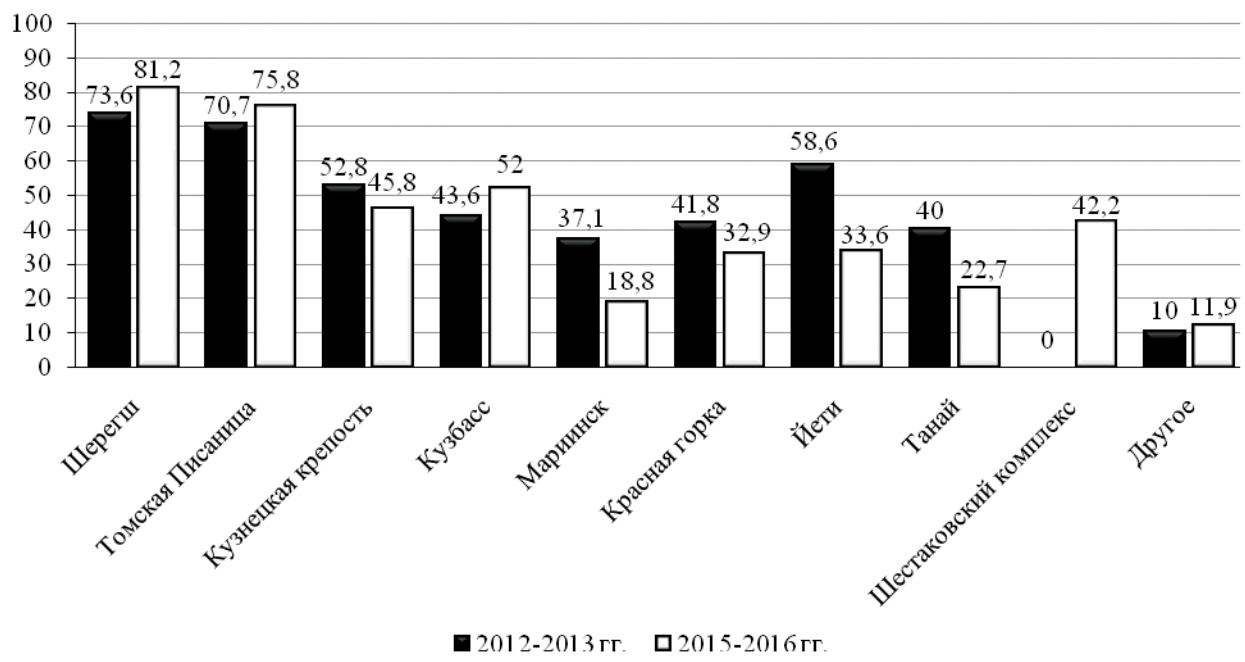

Puc. 3. Сравнительный анализ ответов жителей Кемеровской области о туристском бренде региона (\%) [Fig. 3. Comparative analysis of responses from Kemerovo region residents about the region's tourism brand (\%)]

ше ассоциируется не с регионом в целом, а с горнолыжным курортом «Шерегеш». Кроме того, можно предположить, что часть голосов в опросе за 2015-2016 годов перешла на новый туристский бренд - Шестаковский археологический комплекс, в связи с ростом его популярности.

Далее идут музей-заповедник «Красная горка», горнолыжный курорт «Танай», город-музей под открытым небом Мариинск, показатели по которым за прошедшие годы изменились несущественно.

Но, при этом необходимо помнить, что любой бренд территории складывается из двух составляющих: эмоциональной и рациональной. «Йети» как туристский бренд изначально был создан именно как эмоциональная компонента имиджа (тра- диции, обычаи, атмосфера и т.д.) региона, с целью привлечения туристов в Горную Шорию, а точнее именно в горнолыжный курорт «Шерегеш», но данная территория и так считается самой развитой туристской территорией Кемеровской области. И анализ статистических данных за 20122016 годы подтверждает это, и показывает увеличение туристского потока, прежде всего, именно в Шерегеш (за 2015 год ГК «Шерегеш» посетило около 1,2 млн. туристов с учетом иностранных) [3].

Поэтому, главной задачей туристского брендинга Кузбасса в контексте развития внутреннего и въездного туризма на сегодняшний день должен стать переход к рациональной компоненте имиджа (природа, инфраструктура, рекреационные 
потребности населения, трудовые ресурсы и т.д), а следовательно - привлечению туристов в регион в целом, а не только на его отдельную территорию.

Вышесказанное подтверждает актуальность исследования и говорит о том, что формирование и продвижение туристского бренда территории является одним из ключевых направлений в развитии туризма в Кемеровской области.

\section{СПИСОК ЛИТЕРАТУРЫ}

1. Афанасьев О.Е. Бренд как фактор формирования туристского образа страны. Режим доступа: http:// region-brand.ru/articles/94-brend-kak-faktorformirovaniya-turisticheskogo-obraza-strany (дата обращения 24.12.2018).

2. Блашенкова В. Бренд территории: создание и продвижение. Как это делается в России. Практическое руководство. М., ОАО «Можайский полиграфический комбинат», 2011. 320 c.

3. Брель О.А. Туристская привлекательность как фактор диверсификации экономики ресурсного региона // Вестник Кемеровского государственного университета. Серия: Политические, социологические и экономические науки, 2017, № 3(5), с. 25-28.

4. Брель О.А., Кайзер Ф. Ю. Туристская привлекательность как фактор устойчивого развития региона // Актуальные проблемы гуманитарных и естественных наук, 2015, № 3-1, с. 335-338.

5. Брель О. А., Кайзер Ф. Ю., Макаров К. А. Повышение привлекательности региона в контексте устойчивого развития на примере создания природно-исторического комплекса «Вглубь времен за динозаврами» на территории Кемеровской области // Вестник Воронежского государственного университета. Серия География. Геоэкология, 2017, № 3, с. 12-17.

6. Визгалов Д. В. Брендинг города. М., 2011. 41 с.

7. Домнин В. Н. Брендинг: новые технологии в России. 2-е изд. СПб., 2004. 380 с.

8. Кайзер Ф. Ю., Брель О. А. Роль брендинга региона в практике внутреннего и въездного туризма в России // Туризм в современном мире: направления и тенденции развития. Материалы IV Всероссийской научно-практической конференции с международным участием, посвященной 10-летию кафедры «Социальнокультурный сервис и туризм» под ред. В.А. Чернова. 2013, C. 26-30.

9. Котлер Ф. Основы маркетинга: краткий курс. М., ИД «Вильямс», 2007. 647 с.

10. Кошелев А. А. «Брендинг территорий»: к вопросу о теоретико-методологических аспектах определения понятия // Известия Саратовского университета. Новая серия. Серия Социология. Политология, 2017, т. 17, № 2, с. 133-135.

11. Стась А. Брендинг регионов. Как сделать из бренда туристический бренд? М., 2007.
12. Стратегия развития туристско-рекреационного кластера Кузбасса на период до 2025 года // Коллегия администрации Кемеровской области [принят 03.06.2015 г. №301-p], 2015. 72 c.

13. Федотов С. В., Федотов В. И. Континентальный туризм в России. Современные доминанты // Вестник Вестник Воронежского государственного университета. Сер. География. Геоэкология, 2017, №3, с. 5-11.

14. Ashworth G. City branding: Two questions, two answers and some more questions. Need Geogr Stud 2006(339):54-60.

\section{REFERENCES}

1. Afanas'ev O.E. [Brand as a factor of formation of the tourist image of the country]. (In Russ.) Available at: http://region-brand.ru/articles/94-brend-kak-faktor-formirovaniya-turisticheskogo-obraza-strany accessed 24.12.2018).

2. Blashenkova V. Brend territorii: sozdanie i prodvizhenie. Kak eto delaetsya $v$ Rossii [Brand of territory: the creation and promotion. As is done in Russia]. Moscow, Mozhayskiy poligraficheskiy kombinat Publ., 2011. 320 p. (In Russ.)

3. Brel' O. A. Turistskaya privlekatel'nost' kak faktor diversifikatsii ekonomiki resursnogo regiona [Tourist attraction as a factor of economic diversification of the resource regions]. Vestnik Kemerovskogo gosudarstvennogo universiteta. Seriya: Politicheskie, sotsiologicheskie i ekonomicheskie nauki, 2017, no. 3(5), pp. 25-28. (In Russ.)

4. Brel' O. A., Kayzer F. Yu. Turistskaya privlekatel'nost' kak faktor ustoychivogo razvitiya regiona [Tourism attractiveness as a factor of sustainable development of the region]. Aktual'nye problemy gumanitarnykh i estestvennykh nauk, 2015, no. 3-1, pp. 335-338. (In Russ.)

5. Brel' O. A., Kayzer F. Yu., Makarov K. A. Povyshenie privlekatel'nosti regiona $v$ kontekste ustoychivogo razvitiya na primere sozdaniya prirodno-istoricheskogo kompleksa "Vglub' vremen za dinozavrami" na territorii Kemerovskoy oblasti [Increase attractiveness of the region in the context of sustainable development on the example of the creation of historical-natural complex "Deep into time with the dinosaurs" on the territory of Kemerovo region]. Vestnik Voronegskogo gosudarstvennogo universiteta. Seriya Geografiya, Geoekologiya, 2017, no. 3, pp. 12-17. (In Russ.)

6. Vizgalov D. V. Brending goroda [City Branding]. Moscow, 2011. 41 p. (In Russ.)

7. Domnin V.N. Brending: novye tekhnologii v Rossii [Branding: new technologies in Russia]. SPb., 2004. 380 p. (In Russ.)

8. Kayzer F. Yu., Brel' O. A. [The Role of branding in the region in the practice of domestic and inbound tourism in Russia] Materialy IV Vserossiyskoy nauchno-prakticheskoy konferentsii s mezhdunarodnym uchastiem "Turizm $v$ sovremennom mire: napravleniya i tendentsii razvitiya” [Proc. of IV All-Russian Int. sci.-prac. conf. "Tour- 
ism in the modern world: trends and development trends”]. 2013, pp. 26-30. (In Russ.)

9. Kotler F. Osnovy marketinga: kratkiy kurs [Fundamentals of marketing: a short course]. Moscow, "Vil'yams" Publ., 2007. 647 p. (In Russ.)

10. Koshelev A. A. "Brending territoriy": k voprosu o teoretiko-metodologicheskikh aspektakh opredeleniya ponyatiya [ "Branding": the question of theoretical and methodological aspects of the definition]. Izvestiya Saratovskogo universiteta. Novaya seriya. Seriya Cotsiologiya. Politologiya, 2017, v. 17, no. 2, pp. 133-135. (In Russ.)

11. Stas' A. Brending regionov. Kak sdelat' iz brenda turisticheskiy brend? [Branding of regions. How to make brand travel brand?]. Moscow, 2007. (In Russ.)

\section{КОНФЛИКТ ИНТЕРЕСОВ}

Автор декларирует отсутствие явных и потенциальных конфликтов интересов, связанных с публикацией настоящей статьи.

\section{Кайзер Филипп Юрьевич}

аспирант, ассистент кафедры геологии и географии Кемеровского государственного университета, г. Кемерово, Российская Федерация, ORCID: 0000-0002-6756-6493, e-mail:filipp.kaizer@yandex.ru
12. Strategiya razvitiya turistsko-rekreatsionnogo klastera Kuzbassa na period do 2025 goda [The strategy for the development of the tourism cluster of the Kuzbass for the period until 2025]. Kollegiya administratsii Kemerovskoy oblasti Publ., 2015. 72 p.

13. Fedotov S. V., Fedotov V. I. Kontinental'nyy turizm v Rossii. Sovremennye dominanty [Continental tourism in Russia. Modern dominant]. Vestnik Voronegskogo gosudarstvennogo universiteta. Seriya Geografiya, Geoekologiya, 2017, no. 3, pp. 5-11. (In Russ.)

14. Ashworth G. City branding: Two questions, two answers and some more questions. Need Geogr Stud 2006(339):54-60.

\section{CONFLICT OF INTEREST}

The author declares no information of obvious and potential conflicts of interest related to the publication of this article.

\section{Philipp J. Kaizer}

Postgraduate student, Assistant Professor at Department of Geology and Geography, Kemerovo State University, Kemerovo, Russian Federation, ORCID: 0000-0002-6756-6493, e-mail: filipp.kaizer@yandex.ru 